\title{
A New Methodology for Customer Satisfaction Analysis: Taguchi's Signal-to-Noise Ratio Approach
}

\author{
Li-Hsing Ho ${ }^{1}$, Shu-Yun Feng2 ${ }^{2}$ Tieh-Min Yen ${ }^{*}$ \\ ${ }^{1}$ Department of Technology Management, Chung-Hua University, HsinChu, Taiwan \\ ${ }^{2}$ Department of Hospitality Management, Chung-Hua University, HsinChu, Taiwan \\ Email: ${ }^{*} y$ tm1129@ms48.hinet.net
}

Received 23 October 2013; revised 24 November 2013; accepted 18 December 2013

Copyright (C) 2014 by authors and Scientific Research Publishing Inc.

This work is licensed under the Creative Commons Attribution International License (CC BY). http://creativecommons.org/licenses/by/4.0/

c) (7) Open Access

\begin{abstract}
The purpose of this study was to establish a new methodology for customer satisfaction analysis by using Taguchi Signal-to-Noise Ratio to assess service quality performance to effectively improve customer satisfaction. This study applied the Taguchi Signal-to-Noise Ratio methodology to process the Ordered Categorical Data, and took into account simultaneously the impact of average and variance as well as satisfaction and dissatisfaction information to correctly identify the improvement direction of quality attributes. With Taiwan's standard hotel as the research subject, this study discussed the methodology and benefits of applying Taguchi Signal-to-Noise Ratio to customer satisfaction analysis.
\end{abstract}

\section{Keywords}

Taguchi Signal-to-Noise Ratio, Service Quality, SERVPERF, SERVQUAL, Customer Satisfaction, Standard Hotel

\section{Introduction}

The purpose of this study was to establish a new customer satisfaction analysis methodology by using Taguchi Signal-to-Noise Ratio to assess service quality performance to improve customer satisfaction of Taiwan's standard hotels. Customer satisfaction has become the key impact factor for organizational performance [1] [2], hence, customer satisfaction has become one of the core fields of academic study and industrial application [3]. Such studies usually collect and analyze information of customer perception of product and service quality by

${ }^{*}$ Corresponding author. 
market survey, and furthermore take action plans to win customers and market. In general, customer satisfaction survey has the following objectives:

1) To provide organizations with achievement status and trend analysis in terms of time sequence for the comparison of different markets or regions [4];

2) To drive organizations to implement continuous quality improvement activities [5];

3) To stimulate organizations to focus on product and service innovative activities to segment the market [6].

Studies of the service industry's customer satisfaction usually adopt the Likert Scale to quantify and measure the customer perception and perception level of service quality attributes in most recent transactions [7] [8].

Regarding the studies on the relevance of service quality and customer satisfaction, Naik, et al. and Shahin and Janatyan confirmed that service quality and customer satisfaction are positively correlated, thus improving service quality will enhance customer satisfaction [7] [8]. Regarding studies on the relevance of customer satisfaction and organizational performance, Wiele et al. and Shahin and Janatyan proved in their empirical study that customer satisfaction and organizational performance are positively correlated [8] [9]. Many research have used the satisfaction of service quality attributes as the major measurement indicator in studies of organizational performance.

Service quality is the key determinant and long term competitiveness of the organizational performance [10]. Gronroos suggested that the service quality model is consisted of three functions of technical quality, functional quality, and corporate image. Technical quality refers to the results of interactions between customer and service provider, which can be objectively measured in general [11]. Functional quality refers to the customer perception of service including the service process, which was generally subjective assertion [11]. Garvin pointed out that service quality is user-oriented, namely, quality is subject to the subjective assertions of the customer rather than objective assessment [12].

Parasuraman et al. proposed the conceptual model for service quality gap analysis, suggesting that there are five gaps in the service providing process affecting service quality [13]. Gap 1, Gap 2, Gap 3, Gap 4 are from the service provider arising from internal organizational problems, and Gap 5 that subjects to the customer is originated from the gap between customer expectation and the actual perception. Gap 5 has to be narrowed to satisfy the customer. Hence, the service quality results can be assessed by direct measurement of the customer expected service standards and the actually perceived service quality [14].

Parasuraman et al. proposed the SERVQUAL scale to compare the customer service expectation(E) and perception (P) to assess service quality $(\mathrm{Q})$ by $\mathrm{Q}=\mathrm{P}-\mathrm{E}$ [15] [16]. The introduction of SERVQUAL has led to many applications and empirical studies in many industries [17], as well as scholastic comments and modifications [17]-[20]. Carman used $\mathrm{Q}=\mathrm{W} \times(\mathrm{P}-\mathrm{E})$ to assess service quality, where $\mathrm{W}$ was the weight [18]. Cronin and Taylor proposed the SERVPERF model, and suggested that quality is the customer perceived satisfaction about service performance (P) [19]. When considering the customer perception of the quality attribute significance, it should be $\mathrm{Q}=\mathrm{W} \times \mathrm{P}$. Carrillat et al. pointed out that the advantage of SERVQUAL is to diagnose problems while SERVPERF is aimed at simplifying scale and analyzing quality performance [10]. Regarding the questionnaire design of SERVQUAL, respondents would be often impatient due to too many items of the questionnaire. This may result in deviations in research results. However, SERVPERF cut half of the questionnaire items. Simple and service result-oriented performance assessment was the main advantage of SERVPERF [19].

In studies of SERVQUAL and SERVPERF, ordinal scale is the basis of questionnaire survey and statistical analysis. Most of the discussions are about dimension, reliability, validity and weight [17]-[20], and studies on ordinal scale analysis methodology are rare. Hence, this study adopted the SERVPERF scale, proposing to use the Taguchi Signal-to-Noise Ratio (S/N) customer satisfaction analysis methodology to analyze the service quality performance of Taiwan's standard hotels.

\section{Traditional Customer Satisfaction Analysis Methodology}

The advantages of SERVPERF are easy to use and interpret. Customer perception is generally quantified by Likert rating scale and assessed on the basis of the customer satisfaction of most recent transactions. SERVPERF still have problems worthy of discussions: the most influential one is the use of averages of Ordered Categorical Data as the major statistical amount for analysis that overlooks the differences in customer perception of different quality attributes. Before implementing major decision-making, use methods of lower accuracy for analysis can easily lead to wrong decisions and cause serious losses [21]. 
When regarding Ordered Categorical Data as variable data to calculate the average customer satisfaction of quality attributes, same average customer satisfaction may have different variances, hence, the meanings presented by the data may be totally different. Lee et al., Yang and Yang et al. proposed to use the variance as the benchmark for analysis and comparison [21]-[24]. When the variances presented by the data are the same, it means that customers are consistent regarding service quality satisfaction. In this case, regarding Ordered Categorical Data as the variable data for processing to use the obtained average as the basis of comparison and analysis is reasonable. However, this is only applicable to such special cases. Take 5-point scale as an example, if the average quality attribute customer satisfaction level is 3.25, it means neither "or" nor "satisfied". Hence, without reasonable data conversion, the direct processing of Ordered Categorical Data as variable data may lead to results hard to explain in practice. When the quality attribute satisfaction distribution varies, using averages as the statistic for analysis and comparison may also produce unreasonable phenomena such as data presentation similar to normal distribution and uniform distribution representing different meanings [21].

In case of same averages of service quality attributes, the one with smaller variance has the better quality [25]. Smaller variance means higher quality consistency as customers differ at smaller level in terms of service quality satisfaction [21]. When the data have different satisfaction averages and variance, for example, comparing data of higher average satisfaction and bigger variance with data of lower average statistics, the SERVPERF analysis results of quality attributes of higher averages would be better in performance. However, such results would distort facts. When considering the difference in quality attributes perception of different customers, the quality attribute performance would be just opposite [21]. The impact of differences in customer perception is that it can more easily identify the quality in case of same average satisfaction. The study of Yang adopted the variance as the second decision-making factor of priority to avoid the hard situation of inability to judge in case of same quality attribute averages [25]. The smaller variance is, the better quality is, representing that the customer perception of quality attributes are highly consistent with their cognition. However, in case of different average satisfaction and variance, it is hard to compare and judge quality performance [21]. Hence, this study applied the S/N ratio to analyze the customer satisfaction information by taking into account the average and variance at the same time.

In addition, Ordered Categorical Data are generally processed by the cumulative analysis methodology rather than converted into S/N ratio [25]. The cumulative analysis methodology is first to define accumulative levels and times. The second step is to calculate accumulation probability, and finally describe the probability diagram for direct comparison. However, there will be some difficulties in satisfaction problem analysis as it is unable to describe all quality attributes in a diagram to compare their quality by graphic presentation. Hence, this study did not propose to use the Taguchi accumulative methodology for analysis. However, the accumulative analysis methodology is very effective in summarizing the times and probabilities of various scales as the proportion of satisfaction and dissatisfaction times are regarded as the basic data for service quality performance assessment. However, assessment method to integrate the dissatisfaction and satisfaction data of service quality into an indicator has never been proposed. Hence, this study proposed the Taguchi S/N ratio methodology to solve problems of the traditional satisfaction analysis methodology. The proposed methodology considers the impact of average and variance while integrated satisfaction and dissatisfaction data to assess service quality performance.

\section{Materials and Methodology}

\subsection{Research Subjects}

With Taiwan's standard hotel as the subjects of service quality construction, this study helped improve the current service quality to satisfy customer demands for quality accommodation and improve industrial competitiveness. The research objects included: standard hotels, hotels, guest houses, hostels, recreational vacation centers, motels and inns.

\subsection{Research Method}

The main purpose of this study was to apply the Taguchi Signal-to-Noise Ratio in satisfaction analysis methodology on the basis of Taiwan's standard hotel service quality questionnaire results to consider differences in the customer perception of quality attributes and integrate satisfaction and dissatisfaction data S/N ratio to assess the service quality performance and determine improvement priority. 
For the establishment of standard hotel service quality attributes, this study referred to the recent 20 years' literature of the Emerald and Science Direct database for literature analysis and summary to discuss the service quality attributes of standard hotel by interviews with experts. This study investigated the summarized service quality attributes by questionnaire and randomly selected samples according to the proportions of standard hotels in various regions. Then, the collected data were analyzed by the Taguchi Signal-to-Noise Ratio methodology for the improvement of standard hotel customer satisfaction.

\subsection{Questionnaire Design}

Based on the five service quality dimensions proposed by Parasuraman et al. service quality [15] [16], this study constructed the service quality attributes by referring to the recent 20 years' literature on hotel industrial service quality, and selected 12 experts of relevant industries, governmental officials and academic representatives for expert interview to summarize 38 attributes of standard hotel service quality as the items of the questionnaire.

The service quality performance was assessed by using the SERVPERF questionnaire to understand the actual perceived quality of customers after getting the service. The assessment of customer perceived service quality was implemented by using the 5-point scale with "1" standing for "strongly dissatisfied", 5 standing for "strongly satisfied".

\subsection{Taguchi Signal-to-Noise Ratio}

Taguchi suggested that good quality must meet the following requirement: quality attribute's average and target values should be consistent while the smaller variation of quality attribute would be better [26]. Therefore, quality assessment should take into account both the impact of average and variance at the same time. Peace indicated that $\mathrm{S} / \mathrm{N}$ ratio has considered simultaneously the impact of average and variance in the assessment of quality attribute, and integrated the analysis results from the 2-dimensional model into the one-dimensional model [27]. Hence, S/N ratio has very good additive capability in quality evaluation and prediction [28]. Fowlkes and Creveling argued that the advantage of $\mathrm{S} / \mathrm{N}$ ratio is its ability to reflect the variations of the quality attributes [29]. When implementing quality improvements, $\mathbf{S} / \mathrm{N}$ ratio can independently adjust average values to the target values. The purpose of $\mathrm{S} / \mathrm{N}$ is to implement the comparison of quality performance. Therefore, $\mathrm{S} / \mathrm{N}$ ratio can measure relative quality and the use of $\mathrm{S} / \mathrm{N}$ ratio is simple and with additive capability. Taguchi et al. pointed out that one of the advantages of using $\mathrm{S} / \mathrm{N}$ ratio is its direct link with economy as $\mathrm{S} / \mathrm{N}$ ratio is deduced and varied into the ratio from loss function [25].

The measurement level of the satisfaction survey was the Ordered Categorical Data of count value data type to distinguish count value S/N ratios into the Smaller the Better, The Larger The Better and Ordered Categorical Data [25]. This study used the Larger The Better and the Smaller the Better attributes of the count values to assess the service quality performance, taking into account the impact of average and variance, and integrating the data of satisfaction and dissatisfaction.

In the assessment of customer satisfaction, Likert Scale is generally used in the design of questionnaire to prioritize the actual customer perception of service quality by level. With Likert five-point scale data, this study used the $\mathrm{S} / \mathrm{N}$ ratio to explain the methodology for customer satisfaction, and summarize the questionnaire survey data of the customer satisfaction, as shown in Table 1, where $y_{l}$ represented number of times of answering level $l$ by customers, if the 5-point scale $l=1,2,3,4,5, y_{t}$ represented the number of collected valid questionnaires.

Priority level data can be converted into the data type of count value to distinguish the satisfied and dissatisfied service quality performance. Define level 4 (satisfied) and level 5 (strongly satisfied) as levels of customer satisfaction about service quality; define level 2 (dissatisfied) and level 1 (strongly dissatisfied) as customer dissatisfaction of service quality attributes. Hence, among collected valid questionnaires, the service quality attribute $i$ 's customer satisfaction value was $s_{i}=y_{i 4}+y_{i 5}$, while the service quality attribute i's customer dissatisfaction value was $d_{i}=y_{i 1}+y_{i 2}$. For considering the satisfied and dissatisfied information $\mathrm{S} / \mathrm{N}$ ratio analysis, the satisfaction coefficient $p_{s i}$ and the dissatisfaction coefficient $p_{d i}$ should be calculated as shown in Equation (1).

$$
\begin{aligned}
& p_{s i}=\frac{\left(y_{i 4}+y_{i 5}\right)}{y_{t}} \\
& p_{d i}=\frac{\left(y_{i 1}+y_{i 2}\right)}{y_{t}}
\end{aligned}
$$


Table 1. Customer satisfaction Likert five-point scale data summary.

\begin{tabular}{cccccc}
\hline Level $l$ & 1 & 2 & 3 & 4 & 5 \\
Level & Strongly dissatisfied & Dissatisfied & Fair & Satisfied & Strongly satisfied \\
Number of times & $y_{1}$ & $y_{2}$ & $y_{3}$ & $y_{4}$ & $y_{5}$ \\
\hline
\end{tabular}

where, $i=1,2,3, \ldots, n$ denotes $n$ service quality attributes.

According to data conversion of Equation (1), dissatisfaction coefficient $p_{d i}$ was a the Smaller the Better quality attribute, as customer dissatisfaction was not expected during the service providing process, hence the smaller dissatisfaction coefficient was the better; the satisfaction coefficient $p_{s i}$ is the larger the better quality attribute as larger number represented more customers. After data conversion, $i$-th dissatisfaction coefficient's $\mathrm{S} / \mathrm{N}$ ratio can be represented by Equation (2) while $i$-th satisfaction coefficient $\mathrm{S} / \mathrm{N}$ ratio was represented by Equation (3). Equations (2) and (3) considered the differences in perception of different customers in addition to taking into account of the average values.

$$
\begin{gathered}
S / N_{d i}=\eta_{d i}=-10 \log \left(\frac{p_{d i}}{1-p_{d i}}\right) \\
S / N_{s i}=\eta_{s i}=-10 \log \left(\frac{1-p_{s i}}{p_{s i}}\right)
\end{gathered}
$$

The purpose of the log functions of Equations (2) and (3) was to get the addive capability, and the "-” was to make the quality decision-making consistent while $i=1,2,3, \ldots, n$ represented $n$ service quality attributes. The greater $\eta_{s i}$ value represented better quality, namely the higher customer satisfaction of service quality attributes [21]. Meanwhile, the greater $\eta_{d i}$ value represented higher quality, namely, the lower customer dissatisfaction level about the service quality attributes. Fowlkes and Creveling suggested that the $\mathrm{S} / \mathrm{N}$ has the advantage of addition [29]. Hence, when measuring two groups of data under same conditions and calculating their S/N ratios, the results can be added up when maximizing $\mathrm{S} / \mathrm{N}$ ratio [30]. As a result, Equation (4) Integrated with the $i$-th satisfaction and dissatisfaction data was applied to assess service quality performance.

$$
\eta_{t i}=\eta_{s i}+\eta_{d i}
$$

Similarly, a greater $\eta_{t i}=\eta_{s i}+\eta_{d i}$ denotes better service quality of $i$-th attribute, therefore, this study used it to analyze the service quality attribute performance and determine the improvement priority.

\section{Results \& Analysis}

By literature review, expert interviews with industrial representatives, government officials and scholars, this study established a total 38 standard hotel service qualities attributes as shown in the second column of Table 2, and constructed the SERVPERF questionnaire accordingly to comply with practice and research demands. The survey subjects of this study were customers of Taiwan's standard hotels. We randomly selected samples according to the proportions of standard hotels in various regions to issue 350 questionnaire copies and get back 317 copies at a recovery rate of $90.571 \%$. After removing 39 invalid questionnaire copies, we get a total of $n=$ 278 valid samples.

\subsection{SERVPERF and S/N Analysis Results}

This study calculated the average satisfaction and standard deviation according to the recovered SERVPERF questionnaire as shown in the $9^{\text {th }}$ (Sat) and $10^{\text {th }}$ (Std) columns of Table 2. The average satisfaction of room comfort and atmosphere (T1) was 3.766, and the standard deviation was 0.841. Higher average satisfaction represented better service quality. When standard deviation was used as the benchmark of comparison in case of same averages, the smaller standard deviation represented better quality performance [23] [24]. Sort out quality attributes according to average and standard deviation. As shown in the $11^{\text {th }}$ column of Table 2. [R (S)], room comfort and atmosphere (T1) ranked the $9^{\text {th }}$. According to the analysis results of SERVPERF, standard hotels should keep the first 5 service quality attributes including neatness (T4), quiet rooms (T13), room privacy (REL3), safety (REL1) and simple procedures to make reservations (E1); lower average satisfaction represented 
Table 2. Taguchi's S/N and SERVPERF analysis results.

\begin{tabular}{|c|c|c|c|c|c|c|c|c|c|c|c|}
\hline Code & Dimensions of Service Quality & $\mathrm{y}_{1}$ & $\mathrm{y}_{2}$ & $\mathrm{y}_{3}$ & $\mathrm{y}_{4}$ & $\mathrm{y}_{5}$ & $\eta_{t i}$ & Sat & Std & $\mathrm{R}(\mathrm{S})$ & $\mathrm{R}(\eta)$ \\
\hline $\mathrm{T} 1$ & Room comfort and atmosphere & 2 & 22 & 60 & 149 & 45 & 13.881 & 3.766 & 0.841 & 9 & 4 \\
\hline $\mathrm{T} 2$ & Unique décor & 6 & 16 & 115 & 120 & 21 & 10.783 & 3.482 & 0.805 & 34 & 21 \\
\hline T3 & Good views and landscape & 5 & 19 & 96 & 106 & 52 & 11.441 & 3.651 & 0.921 & 21 & 17 \\
\hline $\mathrm{T} 4$ & Neatness & 6 & 20 & 38 & 130 & 84 & 15.107 & 3.957 & 0.960 & 1 & 3 \\
\hline T5 & Geographic locations & 4 & 19 & 82 & 138 & 35 & 12.617 & 3.651 & 0.839 & 22 & 13 \\
\hline T6 & Parking space, size and convenience & 5 & 25 & 85 & 128 & 35 & 10.688 & 3.586 & 0.886 & 28 & 22 \\
\hline $\mathrm{T} 7$ & Low prices & 6 & 30 & 66 & 143 & 33 & 10.644 & 3.601 & 0.909 & 26 & 26 \\
\hline T8 & Well-groomed personnel & 6 & 12 & 64 & 156 & 40 & 15.381 & 3.763 & 0.829 & 10 & 2 \\
\hline T9 & $\begin{array}{l}\text { Modern facilities (Karaoke, TV, newspapers and } \\
\text { magazines, etc.) }\end{array}$ & 7 & 26 & 78 & 131 & 36 & 10.480 & 3.586 & 0.918 & 27 & 28 \\
\hline $\mathrm{T} 10$ & $\begin{array}{l}\text { Comprehensive facilities (swimming pools, } \\
\text { air-conditioners, conference rooms, saunas and } \\
\text { Internet, etc.) }\end{array}$ & 4 & 36 & 77 & 126 & 35 & 9.132 & 3.547 & 0.921 & 30 & 33 \\
\hline T11 & Hotel marketing (advertising, websites, etc.) & 4 & 22 & 131 & 105 & 16 & 8.733 & 3.385 & 0.774 & 37 & 35 \\
\hline $\mathrm{T} 12$ & Merchandize selling (souvenirs and specialty & 5 & 18 & 175 & 56 & 24 & 6.512 & 3.273 & 0.782 & 38 & 38 \\
\hline $\mathrm{T} 13$ & Quiet rooms & 5 & 14 & 47 & 153 & 59 & 16.413 & 3.888 & 0.857 & 2 & 1 \\
\hline REL1 & Safety & 8 & 23 & 42 & 146 & 59 & 13.498 & 3.809 & 0.959 & 4 & 7 \\
\hline REL2 & Hotel publicity & 6 & 23 & 112 & 116 & 21 & 9.213 & 3.442 & 0.834 & 36 & 32 \\
\hline REL3 & Room privacy & 5 & 24 & 59 & 118 & 72 & 12.681 & 3.820 & 0.974 & 3 & 12 \\
\hline REL4 & Timely completion of promises made to customers & 5 & 33 & 57 & 128 & 55 & 10.852 & 3.701 & 0.977 & 15 & 20 \\
\hline RES1 & Friendly staff & 5 & 27 & 42 & 153 & 51 & 13.262 & 3.784 & 0.917 & 8 & 8 \\
\hline RES2 & Willingness to assist customers & 6 & 31 & 49 & 139 & 53 & 11.626 & 3.727 & 0.967 & 12 & 16 \\
\hline RES3 & $\begin{array}{l}\text { Ability to resolve problems for customers in a } \\
\text { timely manner }\end{array}$ & 8 & 32 & 54 & 140 & 44 & 10.662 & 3.647 & 0.975 & 23 & 23 \\
\hline RES4 & Services meeting the expectations of customers & 5 & 33 & 67 & 125 & 48 & 10.173 & 3.640 & 0.961 & 25 & 29 \\
\hline A1 & $\begin{array}{l}\text { Ability of service staff to provide correct } \\
\text { information }\end{array}$ & 7 & 28 & 64 & 134 & 45 & 10.988 & 3.655 & 0.952 & 20 & 19 \\
\hline A2 & Professionalism of service staff & 6 & 32 & 60 & 134 & 46 & 10.645 & 3.655 & 0.959 & 18 & 25 \\
\hline A3 & Trustworthiness of service staff & 8 & 24 & 70 & 129 & 47 & 11.227 & 3.658 & 0.955 & 17 & 18 \\
\hline A4 & $\begin{array}{l}\text { Customers feeling secure when interacting with } \\
\text { service staff }\end{array}$ & 5 & 20 & 65 & 138 & 50 & 13.251 & 3.748 & 0.896 & 11 & 9 \\
\hline A5 & $\begin{array}{l}\text { Appropriate support to staff to provide better } \\
\text { services }\end{array}$ & 5 & 17 & 80 & 129 & 47 & 13.027 & 3.705 & 0.883 & 14 & 10 \\
\hline A6 & $\begin{array}{l}\text { Mutual assistance among service staff to facilitate } \\
\text { better services }\end{array}$ & 3 & 21 & 86 & 116 & 52 & 12.085 & 3.694 & 0.897 & 16 & 14 \\
\hline E1 & Simple procedures to make reservations & 2 & 24 & 58 & 136 & 58 & 13.499 & 3.806 & 0.890 & 5 & 6 \\
\hline E2 & Convenient accommodation & 3 & 24 & 63 & 122 & 66 & 12.882 & 3.806 & 0.934 & 6 & 11 \\
\hline E3 & Convenient transportation & 6 & 20 & 56 & 140 & 56 & 13.649 & 3.791 & 0.919 & 7 & 5 \\
\hline E4 & Consultation in sightseeing & 5 & 29 & 87 & 127 & 30 & 9.690 & 3.532 & 0.886 & 31 & 31 \\
\hline E5 & $\begin{array}{l}\text { Deployment of barrier-free space and toilets for } \\
\text { mother and children }\end{array}$ & 5 & 34 & 101 & 108 & 30 & 7.811 & 3.446 & 0.905 & 35 & 37 \\
\hline E6 & Food \& beverages & 10 & 29 & 70 & 128 & 41 & 9.778 & 3.579 & 0.983 & 29 & 30 \\
\hline E7 & Whether employees speak foreign languages & 5 & 31 & 100 & 96 & 46 & 8.463 & 3.529 & 0.956 & 32 & 36 \\
\hline E8 & Personalized attention from service staff & 6 & 31 & 89 & 116 & 35 & 8.953 & 3.522 & 0.930 & 33 & 34 \\
\hline E9 & Prioritization of customers' best interest & 2 & 33 & 69 & 129 & 45 & 10.651 & 3.655 & 0.913 & 19 & 24 \\
\hline E10 & Service hours addressing the needs of customers & 2 & 32 & 55 & 142 & 47 & 11.830 & 3.719 & 0.903 & 13 & 15 \\
\hline \multirow[t]{2}{*}{ E11 } & Understanding of special needs of customers & 2 & 31 & 77 & 122 & 46 & 10.546 & 3.644 & 0.911 & 24 & 27 \\
\hline & & & & & & & & 3.654 & 0.907 & & \\
\hline
\end{tabular}


lower service quality, and standard hotels should immediately improve five service quality attributes including merchandize selling (souvenirs and specialties, T12), hotel marketing (advertising, websites... and so on, T11), hotel publicity (REL2), deployment of barrier-free space and toilets for mother and children (E5) and unique decor (T2).

SERVPERF questionnaire data were used to summarize $y_{i}$ value according to Table 1 , namely, customer of satisfaction level at $i$ had $y_{i}$ times of response as shown from the $3^{\text {rd }}$ column to the $7^{\text {th }}$ column as shown in Table 2. With room comfort and atmosphere (T1) as an example, $y_{1}=2, y_{2}=22, y_{3}=60, y_{4}=149, y_{5}=45$. Level 4 and 5 were customer satisfaction level, calculate the satisfaction times of various service quality attribute s $y_{i 4}+y_{i 5}$, where $i=1,2,3, \ldots, 38$. With room comfort and atmosphere (T1) as an example, the satisfaction number of times were $y_{14}+y_{15}=149+45=194$. Calculate satisfaction coefficient $p_{s i}$ by Equation(1), room comfort and atmosphere (T1) satisfaction coefficient $p_{s 1}=\left(y_{14}+y_{15}\right) / y_{t}=194 / 278=0.698$. similarity, calculate the dissatisfaction times of various service quality attributes $y_{i 1}+y_{i 2}$, with room comfort and atmosphere (T1) as an example, the dissatisfaction number of times was $y_{11}+y_{12}=2+22=24$. According to Equation (1), calculate dissatisfaction coefficient $p_{d i}$, room comfort and atmosphere (T1) dissatisfaction coefficient as $p_{d 1}=\left(y_{11}+y_{12}\right) / y_{t}=$ $24 / 278=0.086$. Use Equations (2) and (3) to calculate $\mathrm{S} / \mathrm{N}$ ratio, with room comfort and atmosphere (T1) as example, input $p_{d 1}$ into Equation(2) to calculate $\mathrm{S} / \mathrm{N}$ ratio $\left(\eta_{d 1}\right)$,

$S / N_{d 1}=\eta_{d 1}=-10 \log [0.086 /(1-0.086)]=10.246$; input $p_{s 1}$ into Equation (3) to calculate S/N ratio $\left(\eta_{s 1}\right)$, $S / N_{s 1}=\eta_{s 1}=-10 \log [(1-0.698) / 0.698]=3.635$. According to Equation (4), calculate total performance of satisfaction and dissatisfaction of service quality attributes $\eta_{t i}=\eta_{s i}+\eta_{d i}$, with room comfort and atmosphere (T1) as an example, $\eta_{t 1}=\eta_{s 1}+\eta_{d 1}=3.635+10.246=13.881$, as shown in the $8^{\text {th }}$ column of Table 2 .

Higher $\mathrm{S} / \mathrm{N}$ ratio represented better service quality, sort out quality attributes by $\mathrm{S} / \mathrm{N}$ ratio $\eta_{t i}$ as shown in the $12^{\text {th }}$ column of Table 2 . R ( $\eta$ ) with room comfort and atmosphere (T1) ranking the $4^{\text {th }}$. Considering the average and standard deviation of quality attributes as well as integrating satisfaction and dissatisfaction information, we jointly assess quality performance. The Taguchi $\mathrm{S} / \mathrm{N}$ ratio analysis results suggested that standard hotels should keep the high performance of top five service quality attributes including quiet rooms (T13), well-groomed personnel (T8), neatness (T4), room comfort and atmosphere (T1) and convenient transportation (E3).

Lower $\mathrm{S} / \mathrm{N}$ ratio represented poorer service quality. standard hotels should immediately improve the top five quality attributes including merchandize selling (souvenirs and specialties, T12), deployment of barrier-free space and toilets for mother and children (E5), whether employees speak foreign languages (E7), hotel marketing (advertising, websites... and so on, T11) and personalized attention from service staff (E8).

\subsection{Discussion}

The high performance of service quality items by priority should be kept by Taiwan's standard hotels varied in the results of SERVPERF and S/N ratio analysis. Although the average satisfaction of quiet rooms (T13) should be lower than neatness (T4), however, due to lower standard deviation, the customer cognition was highly consistent, namely, standard hotels provided stable and consistent service quality. In addition, as shown in Table 2, the quiet rooms (T13) dissatisfaction coefficient at 0.068 was lower than that of the neatness (T4) at 0.094 while the quiet rooms (T13) satisfaction coefficient at 0.763 was about equal to the satisfaction coefficient of neatness (T4) at 0.770 , hence, after the $\mathrm{S} / \mathrm{N}$ ratio analysis, the performance of quiet rooms (T13) was better to rise from ranking the second to the first while neatness (T4) dropped from ranking the first to the third. By the SERVPERF analysis, the average of well-groomed personnel (T8) was high and the standard deviation was low and the service quality performance ranked the $10^{\text {th }}$. As the dissatisfaction coefficient 0.065 was the lowest and the satisfaction coefficient 0.705 was high, hence, after $\mathrm{S} / \mathrm{N}$ ratio analysis, the well-groomed personnel (T8) performance was good, rising from ranking the $10^{\text {th }}$ to the second. By the original SERVPERF analysis, the room comfort and atmosphere (T1) average was high and the standard deviation was low, ranking the $9^{\text {th }}$ in terms of service quality performance. As the dissatisfaction coefficient 0.086 was low and the satisfaction coefficient 0.698 was high, hence, by $\mathrm{S} / \mathrm{N}$ ratio analysis, the room comfort and atmosphere (T1) service quality performance was good, rising from ranking the $9^{\text {th }}$ to the $4^{\text {th }}$. By SERVPERF analysis, the convenient transportation (E3) average and standard deviation were high with service quality performance ranking the $7^{\text {th }}$. As the dissatisfaction coefficient at 0.094 was low and the satisfaction coefficient at 0.705 was high, hence, by S/N ratio analysis, the convenient transportation (E3) service quality performance was good, rising from the $7^{\text {th }}$ to the $5^{\text {th }}$. The convenient procedures for make reservations (E1) ranked the $5^{\text {th }}$ in SERVPERF analysis. As the satisfaction 
coefficient 0.698 was lower than that of the convenient transportation (E3) at 0.705 , convenient procedures for make reservations (E1) S/N ratio $\eta_{t 28}=13.499$ was lower than that of the convenient transportation (E3) at 13.649 , hence, the service quality performance rose from the $5^{\text {th }}$ to the $6^{\text {th }}$. Regarding safety (REL1), the performance ranked the fourth by the SERVPERF analysis results as the average satisfaction was higher and the standard deviation was extremely big, it meant that the customer perception varied greatly. Namely, Taiwan's standard hotels varied greatly in the service quality of providing safety (REL1) while the dissatisfaction coefficient at 0.112 was higher than that of the convenient procedures for make reservations (E1) at 0.094. Hence, after the analysis of S/N ratio, the performance ranked the $6^{\text {th }}$. Room privacy (REL3) had higher average and extremely great standard deviation, indicating that customer perceptions varied greatly. Namely, Taiwan's standard hotels varied greatly in service quality regarding room privacy (REL3). Its dissatisfaction coefficient at 0.104 was relatively higher and the satisfaction coefficient at 0.683 was relatively lower, hence, after $\mathrm{S} / \mathrm{N}$ ratio analysis, the room privacy (REL3) service quality performance dropped to the $12^{\text {th }}$.

Ottenbacher and Harrington suggested that the attractiveness of target market and facilities are the source of innovation [31]. Pfeiffer indicated that human resources are increasingly important as competitive advantages from other sources can easily be copied [32]. Ottenbacher and Harrington argued that performance assessment mechanism based on strategic human resources, power delegation, education and training, and service personnel behaviors is the source of hotel service innovation [31]. Hence, standard hotel owners should improve the frontline service personnel to process customer demands to win competitive advantages by power delegation, training and assessment mechanism [30] [33] [34]. Hence, standard hotels should take differentiated strategies to segment the market regarding the target market of high satisfaction [21] [35].

Regarding service quality items for immediate improvement by Taiwan's standard hotels, the results of SERVPERF and S/N ratio analyses slightly differed in priority. As the average satisfaction of the merchandize selling (souvenirs and specialties, T12) was low and the standard deviation was smaller, it represented that customers were highly consistent, the priority ranking of SERVPERF and S/N ratio analyses was consistent, and hence, it is listed as a priority item for improvement. The standard deviation of the deployment of barrier-free space and toilets for mother and children (E5) was greater, indicating that customers had greater differences in perception, indicating that the service quality performance was relatively low in consistence. According to survey results, customers dissatisfied about $\left(y_{1}+y_{2}=39\right)$ were relatively more, namely, the dissatisfaction coefficient at 0.140 was very high; hence, the $\mathrm{S} / \mathrm{N}$ ratio analysis improvement priority rose to the second place. The standard deviation of the satisfaction about whether employees speak foreign languages (E7) was great, indicating that the consistency in this service quality of standard hotels was low and customers dissatisfied about $\left(y_{1}+\right.$ $y_{2}=36$ ) were relatively more as the dissatisfaction coefficient at 0.129 was very high. Hence, the $\mathrm{S} / \mathrm{N}$ ratio improvement priority should be enhanced. Hotel marketing (advertising, websites... and so on, T11) and hotel publicity (REL2) had lower average satisfaction and small standard deviation as well as lower proportion of dissatisfied customers, hence, the $\mathrm{S} / \mathrm{N}$ ratio analysis improvement priority dropped. The improvement priority difference of the SERVPERF and S/N ratio analysis was in the respect of unique decor attribute (T2), which rose to the $21^{\text {st }}$ in terms of service quality performance mainly because of lower standard deviation of satisfaction and low dissatisfaction coefficient at 0.079. Ottenbacher and Harrington suggested that the attractiveness of target market, strategic human resources, power delegation, education and training, and the service personnel behavior-based performance assessment mechanism as well as facilities are the source of innovation of hotel services [31]. Taiwan's standard hotel owners should immediately improve items of poor performance to win competitive advantages [24] [35]. Taguchi et al. indicated that S/N ratio provides the improvement direction of quality attributes, namely, the two-stage methodology of lowering the variation and moving the average toward the target values [25]. Hence, standard hotel owners should first provide consistent service quality to lower variation and then improve performance to enhance customer satisfaction [28]. Regarding items to be immediately improved, this study suggested to lower the dissatisfaction coefficient, move customers with "fair" perception to "satisfied", namely, to enhance satisfaction coefficient.

\section{Conclusions}

SERVPERF uses the questionnaire methodology to survey service quality satisfaction. Researchers regard the Ordered Categorical Data as the count values for analysis to calculate the averages of the service quality satisfaction before sorting them out in priority to find out quality attributes of continuous improvements or mainten- 
ance of competitive advantages to enhance market competitiveness. However, the traditional SERVPERF analysis methodology directly regarded the Ordered Categorical Data as the count values for analysis on the basis of using averages for analysis and comparison. However, it ignored the variability of the perception of different customers and the proportions of satisfaction and dissatisfaction information, resulting in wrong decision-making.

This study applied the Taguchi S/N concept to convert the Ordered Categorical Data into count value data while considered the differences in customer perception as well as the satisfaction and dissatisfaction information by using the Taguchi $\mathrm{S} / \mathrm{N}$ ratio to integrate customer perception of dissatisfaction and satisfaction into a single indicator for visual judgment of quality attributes. Namely, the greater $\mathrm{S} / \mathrm{N}$ ratio represented higher service quality performance or better satisfaction to use the customer feedback information for analysis and decision-making. The modified model did not only remove the potential problems of SERVPERF but also used simple and easy to explain attributes. With the introduction of $\mathrm{S} / \mathrm{N}$ ratio, it provided the quality attribute improvement direction, lowering service quality variation and improving satisfaction average. In other words, it lowered the number of dissatisfied customers and increased number of satisfied customers. Finally, this study used cases of Taiwan's standard hotels to analyze and discuss that using Taguchi count value S/N ratio customer satisfaction analysis model and application can effectively provide information necessary for business decision-making.

\section{References}

[1] William, P. and Naumann, E. (2011) Customer Satisfaction and Business Performance: A Firm-Level Analysis. Journal of Services Marketing, 25, 20-32. http://dx.doi.org/10.1108/08876041111107032

[2] Ramanathan, U. and Ramanathan, R. (2011) Guest’s Perceptions on Factors Influencing Customer Loyalty an Analysis for UK Hotel. International Journal of Contemporary Hospitality Management, 23, 7-25. http://dx.doi.org/10.1108/09596111111101643

[3] Dominici, G. and Guzzo, R. (2010) Customer Satisfaction in the Hotel Industry: A Case Study from Sicily. International Journal of Marketing Studies, 2, 3-12. http://dx.doi.org/10.5539/ijms.v2n2p3

[4] Jones, T.O. and Sasser, W.E. (1995) Why Satisfied Customers Defect. Harvard Business Review, 73, 88-99.

[5] Binshan, L. and Charlotte, A.J. (1997) Some Issues in Conducting Customer Satisfaction Surveys. Journal of Marketing Practice, 3, 4-13. http://dx.doi.org/10.1108/EUM0000000004317

[6] Ulwick, A.W. (2002) Turn Customer Input into Innovation. Harvard Business Review, 80, 91-97.

[7] Naik, C.N.K., Gantasala, S.B. and Prabhakar, G.V. (2010) Service Quality and Its Effect on Customer Satisfaction in Retailing. European Journal of Social Sciences, 16, pp. 239-251.

[8] Shahin, A. and Janatyan, N. (2011) Estimation of Customer Dissatisfaction Based on Service Quality Gap by Correlation and Regression Analysis in Travel Agency. International Journal of Business Management, 6, 99-108. http://dx.doi.org/10.5539/ijbm.v6n3p99

[9] Wiele, T., Boselie, P. and Hesselink, M. (2002) Empirical Evidence for the Relationship between Customer Satisfaction and Business Performance. Managing Service Quality, 12, pp. 184-193. http://dx.doi.org/10.1108/09604520210429259

[10] Carrillat, F.A., Jaramillo, F. and Mulki, J.P. (2007) The Validity of the SERVQUAL and SERVPERF Scales: A MetaAnalytic View of 17 Years of Research across Five Continents. International Journal of Service Industry Management, 18, 472-490. http://dx.doi.org/10.1108/09564230710826250

[11] Gronroos, C. (1984) A Service Quality Model and Its Marketing Implications. European Journal of Marketing, 18, 36-44. http://dx.doi.org/10.1108/EUM0000000004784

[12] Garvin, D.A. (1983) Quality on the Line. Harvard Business Review, 61, 65-73.

[13] Parasuraman, A., Zeithaml, V.A. and Berry, L.L. (1985) A Conceptual Model of Sevice Quality and Its Implications for Future Research. Journal of Marketing, 49, 41-50. http://dx.doi.org/10.2307/1251430

[14] Hu, H.Y, Lee, Y.C. and Yen, T.M. (2010) Service Quality Gaps Analysis Based on Fuzzy Linguistic SERVQUAL with a Case Study in Hospital Out-Patient Services. The TQM Journal, 22, 499-515. http://dx.doi.org/10.1108/17542731011072847

[15] Parasuraman, A., Zeithaml, V.A. and Berry, L.L. (1988) SERVQUAL: A Multi-Item Scale of Measuring Consumer Perceptions of Service Quality. Journal of Retailing, 64, 12-41.

[16] Parasuraman, A., Zeithaml, V. and Berry, L.L. (1991) Refinement and Reassessment of the SERVQUAL Scale. Journal of Retailing, 67, 420-450. 
[17] Ladhari, R. (2008) Alternative Measures of Service Quality: A Review. Managing Service Quality, 18, 65-86. http://dx.doi.org/10.1108/09604520810842849

[18] Carman, J.M. (1990) Consumer Perceptions of Service Quality: An Assessment of the SERVQUAL Dimensions. Journal of Retailing, 66, 33-55.

[19] Cronin, J.J. and Taylor, S.A. (1992) Measuring Service Quality: A Reexamination and Extension. Journal of Marketing, 56, 55-68. http://dx.doi.org/10.2307/1252296

[20] Llosa, S., Chandon, J. and Orsingher, C. (1998) An Empirical Study of Servqual's Dimensionality. The Service Industries Journal, 18, 16-44. http://dx.doi.org/10.1080/02642069800000017

[21] Lee, Y.C., Yen, T.M. and Tsai, C.H. (2008) Modify IPA for Quality Improvement: Taguchi’s Signal-to-Noise Ratio Approach. The TQM Journal, 20, 488-501. http://dx.doi.org/10.1108/17542730810898458

[22] Yang, C.C. (2003) Establishment and Applications of the Integrated Model of Service Quality Measurement. Managing Service Quality, 13, 310-324. http://dx.doi.org/10.1108/09604520310484725

[23] Yang, C.C. (2005) The Refined Kano’s Model and Its Application. Total Quality Management \& Business Excellence, 16, 1127-137. http://dx.doi.org/10.1080/14783360500235850

[24] Yang, C.C., Jou, Y.T. and Cheng, L.Y. (2009) Using Integrated Quality Assessment for Hotel Service Quality. Quality and Quantity, 24, 349-364.

[25] Taguchi, G., Chowdhury, S. and Wu, Y. (2005) Taguchi’s Quality Engineering Handbook. John Wiley \& Sons, Inc., Hoboken, 225-228.

[26] Taguchi, G. (1991) Taguchi Methods: Signal-to-Noise Ratio for Quality Evaluation. 1st Edition, American Suppliers Institute, Dearborn, 78-80.

[27] Peace, G.S. (1993) Taguchi Method: A Hands-On Approach. Addisson-Wesley Publishing Company, Massachusetts, 273-274.

[28] Taguchi, G. (1987) System of Experimental Design: Engineering Methods to Optimize Quality and Minimize Costs. 1st Edition, American Suppliers Institute, Dearborn, 653-655.

[29] Fowlkes, W.Y. and Creveling, C.M. (1995) Engineering Methods for Robust Product Design. First Printing, AddisonWesley Publishing Company, Boston, 53-58.

[30] Joseph, V.R. and Wu, C.F.J. (2002) Operation Window Experiment: A Novel Approach to Quality Improvement. Journal of Quality Technology, 34, 345-354.

[31] Ottenbacher, M.C. and Harrington, R.J. (2010) Strategies for Achieving Success for Innovative versus Incremental New Service. Journal of Services Marketing, 24, 3-15. http://dx.doi.org/10.1108/08876041011017853

[32] Pfeiffer, J. (1994) Competitive Advantage through People: Unleasing the Power of Work Force. Harvard Business School, Boston.

[33] Edgett, S. (1994) The Traits of Successful New Service Development. Journal of Services Marketing, 8, 40-49. http://dx.doi.org/10.1108/08876049410065606

[34] Chebat, J.C. and Kollias, P. (2000) The Impact of Empowerment on Customer Contact Employees’ Roles in Service Organizations. Journal of Service Research, 3, 66-81. http://dx.doi.org/10.1177/109467050031005

[35] Lee, Y.C., Cheng, C.C. and Yen, T.M. (2009) Integrate Kano’s Model and IPA to Improve Order-Winner Criteria: A Study of Computer Industry. Journal of Applied Sciences, 9, 38-48. http://dx.doi.org/10.3923/jas.2009.38.48 
Scientific Research Publishing (SCIRP) is one of the largest Open Access journal publishers. It is currently publishing more than 200 open access, online, peer-reviewed journals covering a wide range of academic disciplines. SCIRP serves the worldwide academic communities and contributes to the progress and application of science with its publication.

Other selected journals from SCIRP are listed as below. Submit your manuscript to us via either submit@scirp.org or Online Submission Portal.
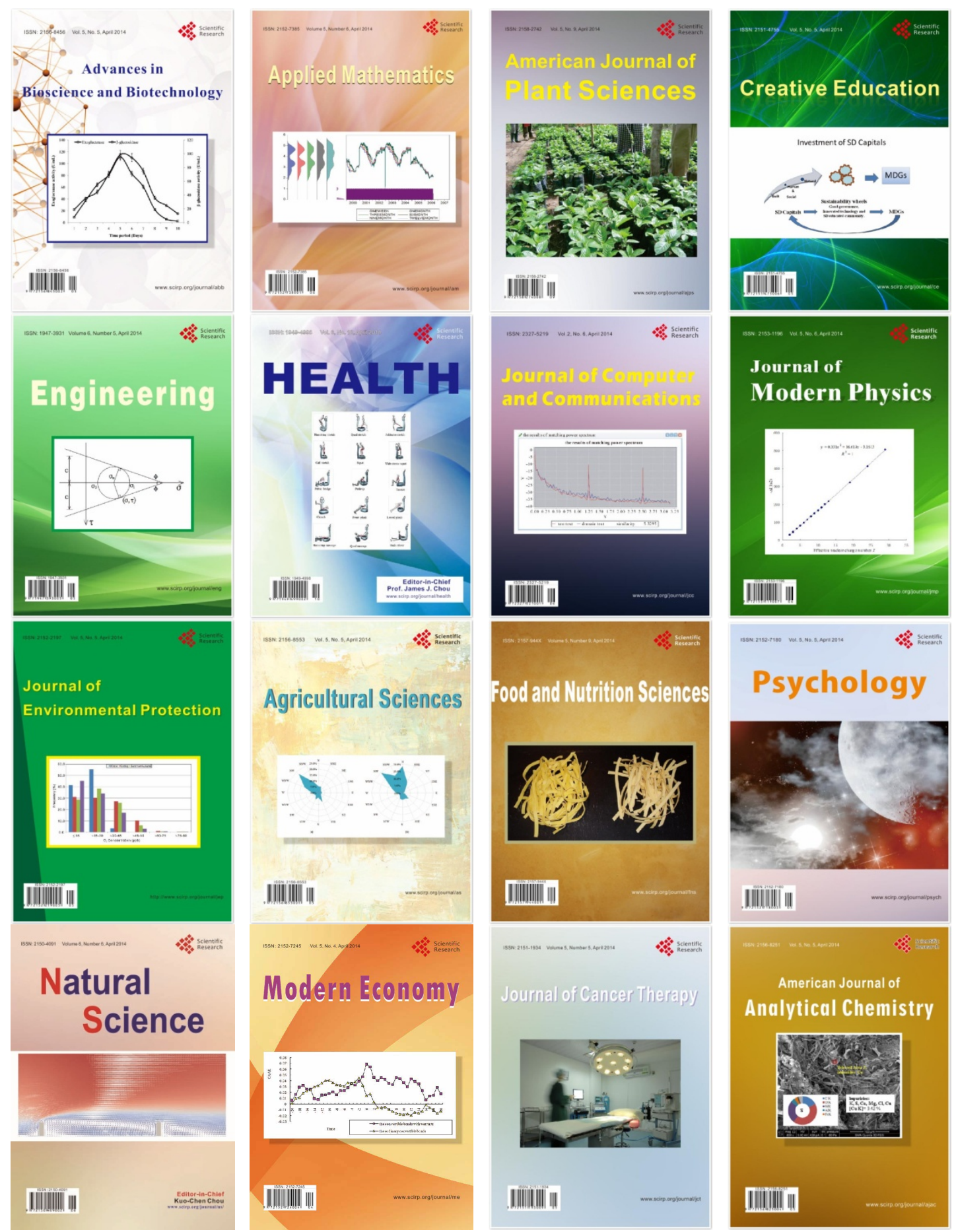